\title{
A BUREAU OF INFORMATION AND REPORT FOR THE INSULAR POSSESSIONS
}

\author{
By Hon. Herbert Parsons, \\ Member of Congress from New York.
}

By law there is not, but there should be, a bureau of information and report for all our insular possessions. The bureau of insular affairs of the War Department, so ably presided over by General Clarence R. Edwards, assisted by Càptain Frank McIntyre, is a bureau of information and report for the Philippine Islands. It handles their interests here, makes their necessary financial arrangements, compiles statistics in regard to them, cares for their students who are being educated in this country, and looks after the purchases that must be made here. It has divisions of correspondence, records, compilation of statistics, accounting, and purchasing and disbursing. He who would get assured facts in regard to any matter in the Philippines can ascertain them from this bureau; from it he can learn the progress made on the new railroads in the Philippines; the prospects of capital being invested in the agricultural bank in the Philippines; conditions in. regard to banking, currency and finance, the amount of seigniorage, and what is being done with it; of the education system and its extent, and of the Roman Catholic Church in the islands, and the schismatic church. Upon inquiry he can ascertain within a few days the number of depositors and amount of deposits in the postal savings bank. The member of congress finds that bureau devoted to the interests of the Philippines, actuated by one motive alone-that of the Philippines for the Filipinos.

Thus a great service to this, the home country, and of potent usefulness to the Philippines is the bureau of insular affairs.

How fare our other insular possessions? Have Porto Rico, Hawaii, Guam, Tutuila and the Midway Islands a similar entity in Washington to inform the country and the legislators of their needs and prospects, and push for and secure the legislation and appropriations they require? No, they have not. They are orphans 
without any sympathetic bureau to assist them and their representatives. No one of these other possessions has by legislation, directly or indirectly, any relation to the bureau of insular affairs. The governor of Porto Rico reports to our Secretary of State, the attorney general of Porto Rico reports to our Attorney General, the treasurer and auditor to our Secretary of the Treasury, the commissioner of the interior to our Secretary of the Interior, and the commissioner of education to our Commissioner of Education. The governor of Hawaii reports to our Secretary of the Interior. The officers in charge of Guam, Tutuila and the Midway Islands are not by law required to make any reports at all.

This parentless condition is a handicap on proper legislation. A year ago Governor Winthrop, of Porto Rico, was anxious that the Porto Rican government should be given power to deal with its water-front, so that the dock facilities of San Juan could be increased. I needed information and sought for some government bureau or official in Washington who would have knowledge of the legal and practical situation sought to be remedied. There was none to be found. It was necessary for Governor Winthrop himself to come here to explain the condition and the need, and push the legislation. The commissioner from Porto Rico was, of course, of assistance, as he is and always will be. But the representatives from our possessions coming here in a legislative capacity, cannot be expected to bring with them, at their own expense, bureaus of statistics and information, and furnish inquirers the facilities which the bureau of insular affairs affords in the case of the Philippines. They can agitate, but for facts and for sympathetic advice and aid, they too, need a department or bureau of the government, just as legislators interested in the Indians need the Indian bureau for information and assistance.

I understand that the commercial interests of Hawaii have been considerably handicapped by her helpless condition, and that the rapacity of our other governmental departments, desirable though it may be, has been such that they have acquired most of the available water-front there simply because there has been no bureau here to look after the interests of the islands and upon which the authorities and merchants of Hawaii could call to speak in their behalf. Who knows aught about Guam, Tutuila or the Midway Islands? 
And yet if we are to possess them we have the sacred duty of providing them the best of what they need in various ways.

In practice these possessions do appeal to the bureau of insular affairs, and so kind-hearted are its officials that they do lend assistance. On the other hand, they are fearful lest their interest unrequired by law, be mistaken for a desire to aggrandize their own importance.

One of our officials most experienced in government in the insular possessions, mindful of the unhappy condition of Porto Rico in this regard, called my attention to the situation and sent me a bill, which I introduced at the recent session of congress. The official was Assistant Secretary of the Treasury Beekman Winthrop, until recently governor of Porto Rico. The bill was entitled, "A bill to secure a better system of report and accountability by the government of the Insular Possessions of the United States," it reads as follows :

Be it enacted by the Senate and House of Representatives of the United States of America in Congress assembled, That all reports now required by law to be made by the executive officers and other officials of the governments of Porto Rico and Hawaii, respectively, to a departmental executive officer at Washington, and copies of all reports now required by law to be made by the aforesaid executive officers and officials to the President, shall hereafter be transmitted, through the bureau of insular affairs, to the Secretary of War, who is hereby empowered to require such additional reports from the officers and officials named as he may deem necessary.

Sec. 2. That the officers in charge of the administration of affairs in Guam, Tuttila, and the Midway Islands, respectively, shall hereafter make report through the bureau of insular affairs to the Secretary of War, who is hereby empowered to require such additional reports from the officers named as he may deem necessary.

President Roosevelt recommended it in substance in his message of December II, I906, on Porto Rico, using the following language:

All the insular governments should be placed in one bureau, either in the Department of War or the Department of State. It is a mistake not so to arrange our handling of these islands at Washington as to be able to take advantage of the experience gained in one when dealing with the problems that from time to time arise in another.

Governor Winthrop said of it:

Such a measure would be helpful in providing an office which could furnish information without delay to officials and others interested in the 
affairs of Porto Rico, Hawaii, etc., and would also afford the officials of one of our insular possessions a better opportunity to benefit by the experience gained in the others. By this means, also, a uniform policy of administration would be insured, the value of which, of course, cannot be overestimated.

The bill had the sympathetic approval of Secretary Root, Secretary Taft, the Honorable Tulio Larrinaga, Resident Commissioner from Porto Rico, and Congressman Hamilton, the chairman of the House Committee on Territories. It was favorably reported by the Committee on Insular Affairs of the House of Representatives, but at so late a date in the session that it was impossible to procure its passage unless there was to be no opposition. Investigation showed that there would be opposition.

Two objections were suggested. One was against such a bureau in the War Department. To some this might appear a valid objection, on the ground that to keep it there marked our policy towards our dependencies as military. But consideration will show that this argument has no substance. The reason for the bureau's development as a bureau of the War Department was a natural one. Our first occupation of these dependencies was a military occupation. The administration of civil affairs within them was necessarily at first a military administration. These dependencies were tropical. They brought up a variety of questions unsolved by any of the departments, divisions or bureaus of the government. There was no governmental subdivision to which they would naturally go for solution. The military having the responsibility, it came as a matter of course that in the War Department, a body of experts should be developed to handle the questions as to detail and originality. This does not mean that the experts were military men. Most of them were not. But it was in the very nature of things that the bureau of insular affairs grew as a bureau of the War Department. This tendency was not a new one. If I am correctly informed, the growth of the colonial office in England happened in much the same way, and that office there was originally a branch of the British War Office. It is not necessary that the bureau should be a bureau of the War Department but, in present conditions, it is desirable that it should be, so that it can have the advantage of the wide experience, great energy and sympathetic 
attitude of such men as Secretary Taft, General Edwards and Captain McIntyre. It is a transferable entity and its location is a matter of practical convenience.

The other objection was that it involved a policy of centralization, would lead to a bureaucracy of colonialdom, and would tend to retain these possessions in a dependent and colonial position instead of relieving us of responsibility for them. That such governmental arrangement has ever been the cause of colonial government, few will believe. It has not prevented England from giving self-government to many of her colonies. On the contrary, it has helped to make England a benefactor in government, in many regions of the earth, and to develop a colonial officialdom of the highest personnel.

Although the bureau of insular affairs is by law limited to the affairs of the Philippine Islands, it has as a practical matter been called upon for service in Santo Domingo and in Cuba. The success that we are attaining in Santo Domingo and in Cuba, is due in no small part to the fact that we have a bureau of insular affairs with an experienced personnel. Governor Magoon, the governor of Cuba, was for many years the law officer of the bureau. The men who will assist him in taking the census of Cuba that will be preparatory to the Cuban elections will be men from the bureau of insular affairs. The men who were sent to Santo Domingo to administer its customs were men from the bureau of insular affairs, familiar with the work to be done because in the early days of the bureau's organization the customs of Cuba, Porto Rico and the Philippines were its principal work. Relieved of the affairs of Cuba on May 20, 1902, it has, not by law but by arrangement, had to do with them since September 29, I906. On May 1, 1900, its duties in regard to Porto Rico ceased, but this year we find the governor of Porto Rico urging that it be made to take them up again. If there are any disadvantages by way of centralization in such a bureau of information and report, they are altogether outweighed by the advantages to us and to our possessions. For many years France maintained a policy of assimilation in French colonization. The various departments of the government had their colonial branches. This was encouraged by the colonial members of the home legislature. It increased their prominence 
and afforded them political profit by way of patronage and strategic position. The general interest of the colonies, however, was not aided by this policy. The inefficiency of the arrangement led the French government in later years to provide a separate ministry for the colonies, and thus to curtail the policy of assimilation.

We have seen how naturally the bureau of insular affairs grew up as a bureau of the War Department, and how, while the military were still in control, it was a bureau of insular affairs for all our insular possessions. When it came to legislation and theorizing, other arrangements seemed possible and even logical. The bureau of insular affairs was deprived of responsibility or power in regard to Porto Rico, and Porto Rico's various department heads were, by legislation, made to report to various department heads here. This was a pretty theory, like the French theory of assimilation. It offended, however, against two principles that apply to the inner workings of government and was an instance of how theory must give way to experience as a truer guide. In the first place, such assimilation and such distribution of the interests of Porto Rico amongst the various departments of the federal government necessarily presumed that the departments would be familiar with the questions that arose. But they were not. There is a waste in acquainting the necessary number of officials in each department with the questions and conditions in dependencies. And to deal with a matter in far-away Porto Rico or Hawaii as against a matter in one of our own states or territories, whose conditions are so much better known, is to deal with the latter first, and with the former last, putting off the affairs of the far-away ones until the convenient season which never comes. The questions and conditions in the far-away possessions must in the end be solved by the officials there. What is needed here, is a bureau of information and energizing force. The other principle which was offended is the one that what is everybody's business is nobody's business, and that unless you place the responsibility and interest in a particular department of the government, which will see to it that needed legislation and appropriations are obtained, little or nothing will be done.

The ways in which a bureau of information and report can be of service to our possesions and to us, are illustrated by the value 
of the bureau of insular affairs to the Philippines. That bureau has, in the first place, created a body of men familiar with conditions there, with the problems that confront us and, to a certain extent, the solutions offered in similar dependencies of other countries. It has provided a place where the legislator can go for accurate information. It has established in the general government a responsible subdivision to which the governments of dependencies must report, a bureau which, by its very being, places a duty of report and accountability upon the governments of dependencies, and is notice to them that there are experts here who will scrutinize the actions of the officials in the colonial possessions. Lastly, and as it seems to me most importantly, it has created a means through which those dependencies may have their wants in the home government and in the home land looked after. In an earlier part of my remarks, I have instanced the aid the present bureau has been to the Philippines in matters affecting them, that are not connected with legislation. Porto Rico needed such aid in making helpful financial arrangements. As to legislation, outsiders do not realize to what an extent legislation is special, and is the result of urging, by special interests, financial, philanthropic, and personal. Certain matters come up by way of routine; some come up by way of orginality on the part of the legislator, but most come up as the result of pressure from the outside. One of the strongest kinds of pressure is that from philanthropists, and from enthusiasts. A bureau of insular affairs is, as you may judge from the bureau of insular affairs for the Philippines, a bureau that would develop enthusiasts, whose enthusiasm would lead them to agitate and educate until the just wishes of those whose responsibilities they bore were met. We have fortunately provided for delegates to congress from Hawaii, Porto Rico and the Philippines. But we need more than them. We need, to inform us, aid them, and energize us, a permanent bureau of information and report which, with the representatives from the localities, will form a body that will care for the interests of our possessions as the agents-general of the selfgoverning colonies and the crown agents of the crown colonies do in England. 